\title{
English-as-a-Second-Language Programs in the Army
}

\author{
Rebecca Oxford-Carpenter and Joan Harman \\ Army Research Institute \\ Janice Redish \\ American Institutes for Research \\ Submitted by \\ Zita M. Simutis, Chief \\ Instructional Technology Systems Technical Area
}

\begin{abstract}
Approved as technically adequate and submitted for publication by Harold F. O'Neil, Jr., Director Training Research Laboratory
\end{abstract}

U.S. ARMY RESEARCH INSTITUTE FOR THE BEHAVIORAL AND SOCIAL SCIENCES 5001 Eisenhower Avenue, Alexandria, Virginia 22333-5600

Office, Deputy Chief of Staff for Personnel Department of the Army

November 1983 